\title{
Genetic relationships between clinical and environmental Vibrio cholerae isolates based on multilocus enzyme electrophoresis
}

\author{
M. Farfán, D. Miñana, M. C. Fusté and J. G. Lorén
}

Author for correspondence: J. G. Lorén. Tel: +34 9340244 97. Fax: +34 934021896. e-mail: loren@farmacia.far.ub.es

Departament de Microbiologia i Parasitologia Sanitàries, Divisió de Ciències de la Salut, Facultat de Farmàcia, Universitat de Barcelona, Avda Joan XXIII s/n, 08028 Barcelona, Spain

\begin{abstract}
A total of 107 isolates of Vibrio cholerae, including 29 strains belonging to serogroup 0139, were studied using multilocus enzyme electrophoresis (MLEE) to determine allelic variation in $\mathbf{1 5}$ housekeeping enzyme loci. All loci were polymorphic and 99 electrophoretic types (ETs) were identified from the total sample. No significant clustering of isolates was detected in the dendrogram generated from a matrix of coefficients of distances with respect to serogroup, biotype or country of isolation. The mean genetic diversity of this $\boldsymbol{V}$. cholerae population $(H=0.50)$ was higher than reported previously. Linkage disequilibrium analysis of the MLEE data showed a clonal structure for the entire population, but not in some of the population subgroups studied. This suggests an epidemic population structure. The results showed that the 0139 strains were not clustered in a unique ET, in contrast to previous MLEE studies. This higher genetic variation of the 0139 serogroup is concordant with ribotyping studies. The results also confirm that the 0139 and 01 ElTor isolates are genetically more closely related to each other than to all the other subpopulations of $\boldsymbol{V}$. cholerae studied.
\end{abstract}

Keywords: MLEE, linkage disequilibrium, cholera, population genetics, electrophoretic types

\section{INTRODUCTION}

Vibrio cholerae is an autochthonous inhabitant of marine and freshwater environments, which is often associated with phyto- and zooplankton (Baumann et al., 1984; Colwell \& Huq, 1994). This bacterium is classified, by the composition of its major surface antigen $(\mathrm{O})$, into serogroups, of which there are nearly 200 (Beltrán et al., 1999). Important distinctions within the species are made on the basis of serogroup, production of cholera toxin, which is responsible for severe diarrhoea, and potential for epidemic spread. Only two serogroups of $V$. cholerae, $\mathrm{O} 1$ and $\mathrm{O} 139$, have been considered as causative agents of cholera, but some strains of these serogroups do not produce cholera toxin and are not involved in epidemics. All the others serogroups, non-O1/non-O139, are more frequently isolated from environmental sources and are associated with sporadic cases of gastroenteritis or extraintestinal

Abbreviations: AFLP, amplified fragment length polymorphism; ET, electrophoretic type; MLEE, multilocus enzyme electrophoresis; RAPD, random amplified polymorphic DNA. infections. Although occasional strains can produce cholera toxin or other virulence factors, none of them has caused large epidemics (Kaper et al., 1995).

Historically, it seems most probable that cholera emerged after the Neolithic, which began in the Middle East some 10000 years ago, when the adoption of agricultural practices by nomadic groups enabled higher densities of humans to subsist (Byun et al., 1999). There are references to deaths due to dehydrating diarrhoea dating back to Hippocrates and Sanskrit writings (Colwell, 1996). Cholera has been endemic on the Indian subcontinent for centuries. The literature describes the first pandemic spread of cholera outside Asia in 1817 (Blake, 1994). Since then seven pandemics have been recorded. The fifth and sixth were caused by the classical biotype of O1 strains, but the nature of the strains causing the first four pandemics is unknown. In contrast, in 1961 the seventh pandemic started in Indonesia and was due to the ElTor biotype. Recently, in 1992 an epidemic clone of a non-O1 strain with serogroup O139 Bengal caused a large cholera outbreak in Bangladesh and neighbouring countries (Albert et al., 1993; Ramamurthy et al., 1993). Several studies have shown 
that the O139 strain is phylogenetically and phenotypically very similar to the O1 ElTor strain, and most probably derived from an $\mathrm{O} 1$ seventh-pandemic clone strain by horizontal gene transfer (Bik et al., 1995; Stroeher et al., 1997). At the beginning of the outbreak, the O139 strain totally displaced the $V$. cholerae O1 strains, including both classical and ElTor biotypes, which coexisted only in Bangladesh. The subsequent emergence of a new clone of V. cholerae O1 ElTor that transiently displaced the O139 strains during 1994 and 1995, and the reemergence in 1996 of V. cholerae O139 as the main cause of cholera in Calcutta and its coexistence with the O1 ElTor strains demostrated temporal changes in the epidemiology of the cholera (Faruque et al., 1997a, b; Mukhopadhyay et al., 1998). The factors that determine the emergence, disappearance or continued presence of particular clones of toxigenic $V$. cholerae are not clear.

The continual emergence of new toxigenic strains of $V$. cholerae and their selective enrichment during cholera outbreaks constitute essential mechanisms for the survival and evolution of $V$. cholerae and the genetic elements that mediate the transfer of virulence genes (Faruque et al., 1998). The molecular mechanisms of cholera pathogenesis are currently being elucidated, as exemplified by the description of the lysogenic filamentous bacteriophage (CTX $\phi)$, which encodes cholera toxin (Waldor \& Mekalanos, 1996), and its receptor, the TCP (toxin-coregulated pilus), which is part of a larger genetic element, the TCP pathogenicity island (Karaolis et al., 1998). These findings may help us to understand the possible origin of new toxigenic clones of $V$. cholerae, and raise the possibility that all strains of $V$. cholerae have the potential to become agents of epidemic cholera (Faruque et al., 1998).

New analysis methods have permitted studies of the genetic variability of $V$. cholerae on a global scale (Faruque et al., 1998). One of them is MLEE, which analyses the electrophoretic mobility differences in multiple enzymes to study divergence of bacterial strains of the same species. Previous studies were primarily concerned with the analysis of strains belonging to the serogroup O1, collected during outbreaks, which were responsible for cholera epidemics and pandemics (Salles \& Momen, 1991; Wachsmuth et al., 1993; Evins et al., 1995). More recently, Beltrán et al. (1999) applied the MLEE technique to the study of a collection of $V$. cholerae isolates from Mexico and Guatemala; they also included reference strains of all serogroups (toxigenic and non-toxigenic). Moreover, various molecular techniques such as PFGE, RAPD and ribotyping have also been applied in attempts to establish the genetic population structure of $V$. cholerae. Recent work in this field includes the comparative nucleotide sequence analysis of pathogenic isolates (Byun et al., 1999) and the AFLP fingerprinting of clinical and environmental isolates (Jiang et al., 2000). However, the relationship of the pathogenic clones with the environmental isolates remains unclear. In the present study, we analysed by MLEE a collection of $V$. cholerae strains isolated from several countries, including toxigenic (O1 and O139) and non-toxigenic serogroups from environmental and clinical sources, to determine the population structure of V. cholerae.

\section{METHODS}

Bacterial strains. This study was carried out on a collection of 100 isolates of Vibrio cholerae, from several countries, including toxigenic (O1 and O139) and non-toxigenic serogroups, obtained from clinical and environmental sources (Table 1). Strains were kindly provided by G. B. Nair (National Institute of Cholera \& Enteric Diseases, Calcutta, India), M. A. R. Chowdhury (Marine Laboratory, Department of Microbiology, University of Maryland, MD 20740, USA) and M. Talledo (Laboratorio Microbiología y Biotecnología Microbiana, Facultad de Ciencias Biológicas, Universidad Nacional Mayor de San Marcos, Lima, Peru). Six reference strains of $V$. cholerae from the Spanish Type Culture Collection (CECT 514, CECT 569, CECT 652, CECT 655, CECT 658 and CECT 659) and a reference strain of classical O1 V.cholerae (ATCC 14035) were also included in the study.

Preparation of lysates for electrophoresis. Each isolate was grown overnight at $35^{\circ} \mathrm{C}$ in Trypticase Soy Broth (TSB), in a shaker. The cells were harvested by centrifugation $(7000 \mathrm{~g}$ for 15 min at $6^{\circ} \mathrm{C}$ ), suspended in TE-NADP buffer (Tris/HCl 10 $\mathrm{mM}$, EDTA $1 \mathrm{mM}$ and NADP $0.5 \mathrm{mM}, \mathrm{pH} 6.8)$ and lysed by freezing and thawing. The cell extracts were obtained after three repeated freezing-thawing cycles $\left(\right.$ at $-20^{\circ} \mathrm{C}$ for $12-24 \mathrm{~h}$ and at $36.6{ }^{\circ} \mathrm{C}$ for $5 \mathrm{~min}$ ) and centrifugation at $110000 \mathrm{~g}$ for $25 \mathrm{~min}$ at $6^{\circ} \mathrm{C}$. Aliquots of supernatant were transferred to Eppendorf tubes and stored at $-40^{\circ} \mathrm{C}$ until use. Protein was measured by the Lowry method, with bovine serum albumin (Sigma) as a standard.

Electrophoresis and specific enzyme staining. Nondenaturing vertical polyacrylamide gel electrophoresis was used for all the enzymes. The acrylamide concentration in the gels depended on the enzyme studied $10 \%$ continuous polyacrylamide gels and $10 \% / 8 \%$ or $8 \% / 5 \%$ discontinuous polyacrylamide gels). Tris $/ \mathrm{HCl} 0.8 \mathrm{M}(\mathrm{pH} 8.8)$ buffer was used in continuous gels and Tris/ $\mathrm{HCl} 0.125 \mathrm{M}(\mathrm{pH} 6.8)$ stacking buffer and Tris/ $\mathrm{HCl} 0.4 \mathrm{M}(\mathrm{pH} 8.8)$ resolving buffer were used in discontinuous gels. Tris/glycine $0.19 \mathrm{M}$ (pH 8.3) buffer was used for the electrode compartments. Gels were used within $24 \mathrm{~h}$ of preparation and run at $7^{\circ} \mathrm{C}$. A constant voltage, depending on the acrylamide concentration of the gel, was applied until the bromophenol blue band reached the bottom of the gel. All strains were run at least twice to confirm their genotype.

The staining of the gels to reveal specific enzyme activity was performed following Selander et al. (1986), except in the case of catechol 2,3-oxygenase (Gibson, 1971; Kataeva \& Golovleva, 1990). The following 15 enzymes were assayed: glucose-6-phosphate dehydrogenase (G6P), isocitrate dehydrogenase (IDH), alanine dehydrogenase (ALD), NADdependent glyceraldehyde-phosphate dehydrogenase (GP1), malate dehydrogenase ( $\mathrm{MDH})$, fumarase (FUM), aspartate dehydrogenase (ASD), leucine aminopeptidase (LAP), malic enzyme (ME), esterase (EST), catechol 2,3-oxygenase (C23O), nucleoside phosphorylase (NSP), xanthine dehydrogenase (XDH), phosphoglucose isomerase (PGI) and 6-phosphogluconate dehydrogenase (6PG). For each enzyme, distinct mobility variants were designated as electromorphs and numbered in order of increasing migration towards the anode. 
Table 1. Characteristics of the bacterial isolates used in this study and their allele profiles at each locus

\begin{tabular}{|c|c|c|c|c|c|c|c|c|c|c|c|c|c|c|c|c|c|c|c|c|}
\hline \multirow[t]{2}{*}{ ET } & \multirow{2}{*}{$\begin{array}{l}\text { No. of } \\
\text { strains }\end{array}$} & \multirow{2}{*}{$\begin{array}{l}\text { Reference } \\
\text { isolates }\end{array}$} & \multicolumn{15}{|c|}{ Allele at enzyme locus } & \multirow[t]{2}{*}{ Serogroup/biotype } & \multirow[t]{2}{*}{ Source* } & \multirow[t]{2}{*}{ Country } \\
\hline & & & G6P & IDH & ALD & GP1 & $\mathrm{MDH}$ & FUM & ASD & LAP & ME & EST & $\mathrm{C} 23 \mathrm{O}$ & NSP & $\mathrm{XDH}$ & PGI & $6 \mathrm{PG}$ & & & \\
\hline 1 & 1 & TM35123-77 & 4 & 3 & 1 & 1 & 1 & 3 & 2 & 7 & 1 & 1 & 2 & 3 & 1 & 4 & 1 & non-O1/non-O139 & $\mathrm{E}$ & Brazil \\
\hline \multirow[t]{2}{*}{2} & 2 & TM34162-77 & 4 & 3 & 1 & 2 & 1 & 3 & 2 & 4 & 1 & 1 & 2 & 3 & 1 & 4 & 1 & non-O1/non-O139 & $\mathrm{E}$ & Brazil \\
\hline & & TM9024-79 & 4 & 3 & 1 & 2 & 1 & 3 & 2 & 4 & 1 & 1 & 2 & 3 & 1 & 4 & 1 & non-O1/non-O139 & $\mathrm{E}$ & Brazil \\
\hline 3 & 1 & TM52479-78 & 4 & 3 & 1 & 2 & 1 & 2 & 1 & 5 & 2 & 2 & 1 & 3 & 1 & 4 & 6 & non-O1/non-O139 & $\mathrm{E}$ & Brazil \\
\hline 4 & 1 & TM23256-79 & 3 & 3 & 1 & 1 & 1 & 2 & 1 & 5 & 2 & 2 & 1 & 3 & 1 & 2 & 1 & non-O1/non-O139 & $\mathrm{E}$ & Brazil \\
\hline 5 & 1 & TM19225-79 & 3 & 1 & 1 & 5 & 1 & 4 & 2 & 5 & 2 & 2 & 1 & 3 & 4 & 2 & 3 & non-O1/non-O139 & $\mathrm{E}$ & Brazil \\
\hline 6 & 1 & GGPB10 & 3 & 3 & 1 & 2 & 1 & 2 & 1 & 5 & 2 & 2 & 1 & 3 & 5 & 3 & 5 & non-typed & $\mathrm{U}$ & Brazil \\
\hline 7 & 1 & TM1705-82 & 3 & 3 & 1 & 2 & 1 & 5 & 2 & 5 & 2 & 2 & 2 & 3 & 1 & 3 & 1 & non-O1/non-O139 & $\mathrm{E}$ & Brazil \\
\hline \multirow[t]{3}{*}{8} & 3 & TM48733-82 & 4 & 3 & 1 & 3 & 2 & 3 & 2 & 7 & 1 & 1 & 2 & 3 & 1 & 4 & 1 & non-O1/non-O139 & $\mathrm{E}$ & Brazil \\
\hline & & TM11079-80 & 4 & 3 & 1 & 3 & 2 & 3 & 2 & 7 & 1 & 1 & 2 & 3 & 1 & 4 & 1 & O1 ElTor & $\mathrm{E}$ & Brazil \\
\hline & & CO484 & 4 & 3 & 1 & 3 & 2 & 3 & 2 & 7 & 1 & 1 & 2 & 3 & 1 & 4 & 1 & non-O1/non-O139 & $\mathrm{E}$ & India \\
\hline 9 & 1 & TM1187-83 & 3 & 3 & 1 & 2 & 1 & 4 & 2 & 5 & 3 & 2 & 1 & 3 & 4 & 3 & 1 & non-O1/non-O139 & $\mathrm{E}$ & Brazil \\
\hline 10 & 1 & CT10738-92 & 3 & 3 & 1 & 2 & 1 & 6 & 2 & 5 & 3 & 2 & 1 & 3 & 4 & 3 & 3 & non-O1/non-O139 & $\mathrm{E}$ & Brazil \\
\hline 11 & 1 & CT10834-92 & 3 & 3 & 1 & 2 & 1 & 4 & 0 & 5 & 2 & 2 & 1 & 3 & 4 & 2 & 5 & non-O1/non-O139 & $\mathrm{E}$ & Brazil \\
\hline 12 & 1 & CT12009-92 & 3 & 4 & 1 & 2 & 3 & 4 & 3 & 2 & 5 & 2 & 2 & 3 & 1 & 3 & 1 & non-O1/non-O139 & $\mathrm{E}$ & Brazil \\
\hline 13 & 1 & GGPB29 & 3 & 3 & 1 & 1 & 1 & 5 & 2 & 5 & 3 & 2 & 1 & 3 & 1 & 2 & 1 & non-typed & $\mathrm{U}$ & Brazil \\
\hline 14 & 1 & GM30-90 & 3 & 2 & 1 & 2 & 3 & 3 & 3 & 3 & 4 & 2 & 3 & 3 & 1 & 3 & 3 & non-O1/non-O139 & $\mathrm{E}$ & Brazil \\
\hline 15 & 1 & GM31-90 & 4 & 3 & 1 & 1 & 1 & 3 & 2 & 7 & 3 & 1 & 2 & 3 & 1 & 4 & 1 & non-O1/non-O139 & $\mathrm{E}$ & Brazil \\
\hline 16 & 1 & GM33-90 & 3 & 3 & 1 & 1 & 1 & 2 & 1 & 5 & 2 & 2 & 1 & 3 & 1 & 2 & 5 & non-O1/non-O139 & $\mathrm{E}$ & Brazil \\
\hline 17 & 1 & GM34-90 & 3 & 3 & 1 & 2 & 1 & 2 & 1 & 5 & 2 & 2 & 1 & 3 & 1 & 2 & 1 & non-O1/non-O139 & $\mathrm{E}$ & Brazil \\
\hline 18 & 1 & GM35-90 & 4 & 3 & 1 & 2 & 1 & 3 & 2 & 1 & 3 & 1 & 2 & 3 & 1 & 4 & 1 & non-O1/non-O139 & $\mathrm{E}$ & Brazil \\
\hline 19 & 1 & GM36-90 & 4 & 1 & 1 & 2 & 1 & 3 & 2 & 7 & 3 & 1 & 2 & 3 & 4 & 4 & 1 & non-O1/non-O139 & $\mathrm{E}$ & Brazil \\
\hline 20 & 1 & GM37-90 & 3 & 3 & 1 & 2 & 1 & 5 & 2 & 5 & 3 & 2 & 1 & 3 & 1 & 3 & 1 & non-O1/non-O139 & $\mathrm{E}$ & Brazil \\
\hline 21 & 1 & GM38-90 & 2 & 3 & 1 & 2 & 1 & 4 & 2 & 1 & 3 & 2 & 3 & 3 & 1 & 4 & 1 & non-O1/non-O139 & $\mathrm{E}$ & Brazil \\
\hline 22 & 1 & CT7606-93 & 6 & 3 & 1 & 3 & 2 & 3 & 2 & 7 & 1 & 1 & 1 & 3 & 4 & 4 & 1 & O1 ElTor & $\mathrm{E}$ & Brazil \\
\hline 23 & 1 & СТ9995-93 & 4 & 3 & 1 & 1 & 1 & 3 & 2 & 7 & 3 & 1 & 1 & 3 & 4 & 4 & 1 & O1 ElTor & $\mathrm{E}$ & Brazil \\
\hline 24 & 1 & GGPB44 & 4 & 2 & 1 & 1 & 1 & 3 & 2 & 7 & 1 & 1 & 2 & 3 & 1 & 4 & 1 & non-typed & $\mathrm{U}$ & Brazil \\
\hline \multirow[t]{2}{*}{25} & 2 & TM207832-78 & 4 & 3 & 1 & 2 & 2 & 3 & 2 & 4 & 1 & 1 & 2 & 3 & 1 & 4 & 1 & O1 ElTor & $\mathrm{E}$ & Brazil \\
\hline & & ALVC-92-0344 & 4 & 3 & 1 & 2 & 2 & 3 & 2 & 4 & 1 & 1 & 2 & 3 & 1 & 4 & 1 & O1 ElTor & $\mathrm{C}$ & Peru \\
\hline 26 & 1 & CT25016-91 & 6 & 3 & 1 & 3 & 2 & 3 & 2 & 7 & 1 & 1 & 1 & 3 & 4 & 4 & 3 & O1 ElTor & $\mathrm{E}$ & Brazil \\
\hline 27 & 1 & CT7021-94 & 6 & 3 & 1 & 2 & 2 & 3 & 2 & 3 & 1 & 1 & 2 & 3 & 4 & 4 & 1 & O1 ElTor & $\mathrm{E}$ & Brazil \\
\hline 28 & 1 & TM16457-78 & 3 & 3 & 1 & 1 & 1 & 4 & 1 & 5 & 3 & 2 & 1 & 3 & 1 & 3 & 5 & O1 classical & $\mathrm{E}$ & Brazil \\
\hline 29 & 1 & CT7649-94 & 4 & 3 & 1 & 2 & 2 & 3 & 2 & 7 & 1 & 1 & 2 & 3 & 1 & 4 & 1 & O1 ElTor & $\mathrm{E}$ & Brazil \\
\hline 30 & 1 & $\begin{array}{l}\text { CTMARMI2- } \\
92\end{array}$ & 4 & 3 & 1 & 1 & 1 & 3 & 2 & 1 & 3 & 1 & 2 & 3 & 1 & 4 & 3 & O1 ElTor & $\mathrm{E}$ & Brazil \\
\hline 31 & 1 & $\begin{array}{l}\text { CTMACMI1- } \\
92\end{array}$ & 3 & 3 & 1 & 2 & 2 & 4 & 2 & 6 & 3 & 1 & 2 & 3 & 1 & 4 & 1 & O1 ElTor & $\mathrm{E}$ & Brazil \\
\hline
\end{tabular}




\begin{tabular}{|c|c|c|c|c|c|c|c|c|c|c|c|c|c|c|c|c|c|c|c|c|}
\hline \multirow[t]{2}{*}{ ET } & \multirow{2}{*}{$\begin{array}{l}\text { No. of } \\
\text { strains }\end{array}$} & \multirow{2}{*}{$\begin{array}{l}\text { Reference } \\
\text { isolates }\end{array}$} & \multicolumn{15}{|c|}{ Allele at enzyme locus } & \multirow[t]{2}{*}{ Serogroup/biotype } & \multirow[t]{2}{*}{ Source* } & \multirow[t]{2}{*}{ Country } \\
\hline & & & G6P & IDH & ALD & GP1 & $\mathrm{MDH}$ & FUM & ASD & LAP & ME & EST & $\mathrm{C} 23 \mathrm{O}$ & NSP & $\mathrm{XDH}$ & PGI & 6PG & & & \\
\hline 32 & 1 & MX121 & 3 & 1 & 1 & 2 & 1 & 4 & 1 & 5 & 2 & 2 & 1 & 3 & 1 & 2 & 5 & non-O1/non-O139 & $\mathrm{F}$ & Mexico \\
\hline 33 & 1 & MX129 & 3 & 3 & 1 & 1 & 1 & 2 & 1 & 5 & 2 & 2 & 2 & 1 & 1 & 3 & 1 & non-O1/non-O139 & $\mathrm{F}$ & Mexico \\
\hline 34 & 1 & MX134 & 4 & 3 & 1 & 1 & 1 & 3 & 2 & 7 & 1 & 2 & 1 & 3 & 1 & 2 & 5 & non-O1/non-O139 & $\mathrm{F}$ & Mexico \\
\hline 35 & 1 & MX157 & 4 & 3 & 1 & 1 & 2 & 3 & 2 & 2 & 1 & 1 & 2 & 3 & 1 & 4 & 1 & non-O1/non-O139 & $\mathrm{F}$ & Mexico \\
\hline 36 & 1 & MX158 & 3 & 3 & 1 & 2 & 1 & 5 & 1 & 5 & 3 & 2 & 1 & 3 & 1 & 3 & 1 & non-O1/non-O139 & $\mathrm{F}$ & Mexico \\
\hline 37 & 1 & MX159 & 4 & 3 & 1 & 3 & 2 & 3 & 2 & 2 & 1 & 1 & 2 & 3 & 1 & 3 & 1 & non-O1/non-O139 & $\mathrm{F}$ & Mexico \\
\hline 38 & 1 & AT01 & 4 & 2 & 1 & 2 & 1 & 3 & 2 & 4 & 1 & 1 & 2 & 3 & 1 & 4 & 1 & non-O1/non-O139 & $\mathrm{C}$ & India \\
\hline 39 & 1 & CO391 & 4 & 3 & 1 & 2 & 1 & 5 & 2 & 5 & 3 & 2 & 1 & 3 & 1 & 2 & 5 & $\mathrm{O} 139$ & $\mathrm{~F}$ & India \\
\hline 40 & 1 & $\mathrm{CO} 407$ & 3 & 3 & 1 & 2 & 1 & 4 & 2 & 5 & 3 & 2 & 2 & 3 & 1 & 3 & 1 & O139 & $\mathrm{F}$ & India \\
\hline 41 & 1 & CO487 & 4 & 1 & 1 & 2 & 1 & 3 & 2 & 4 & 3 & 1 & 2 & 3 & 4 & 4 & 1 & O1 ElTor & $\mathrm{C}$ & India \\
\hline 42 & 1 & CO870 & 3 & 4 & 1 & 1 & 1 & 2 & 1 & 3 & 2 & 2 & 1 & 3 & 4 & 3 & 5 & O1 ElTor & $\mathrm{E}$ & India \\
\hline 43 & 1 & SG24 & 3 & 1 & 1 & 2 & 1 & 3 & 2 & 1 & 1 & 2 & 1 & 3 & 1 & 4 & 3 & O139 & $\mathrm{C}$ & India \\
\hline 44 & 1 & CECT514 & 6 & 3 & 1 & 2 & 2 & 7 & 2 & 2 & 3 & 1 & 1 & 3 & 6 & 4 & 2 & O1 classical & $\mathrm{F}$ & UK \\
\hline 45 & 1 & СЕCT569 & 6 & 1 & 1 & 2 & 2 & 7 & 2 & 1 & 1 & 1 & 1 & 3 & 4 & 4 & 1 & O1 classical & $\mathrm{C}$ & India \\
\hline 46 & 1 & CECT652 & 6 & 3 & 1 & 2 & 2 & 7 & 2 & 2 & 3 & 1 & 2 & 3 & 1 & 4 & 1 & O1 & $\mathrm{C}$ & Unknown \\
\hline 47 & 1 & CECT655 & 4 & 3 & 1 & 2 & 2 & 7 & 2 & 2 & 3 & 1 & 2 & 3 & 5 & 4 & 1 & non-O1/non-O139 & $\mathrm{E}$ & Bangladesh \\
\hline 48 & 1 & CECT658 & 6 & 3 & 1 & 3 & 2 & 3 & 2 & 2 & 1 & 1 & 2 & 3 & 4 & 4 & 1 & non-O1/non-O139 & $\mathrm{E}$ & Bangladesh \\
\hline 49 & 1 & СЕСТ659 & 6 & 3 & 2 & 3 & 2 & 3 & 2 & 2 & 1 & 1 & 1 & 3 & 1 & 4 & 4 & non-O1/non-O139 & $\mathrm{E}$ & Bangladesh \\
\hline 50 & 1 & $1-7 / 31$ & 4 & 3 & 1 & 2 & 2 & 3 & 2 & 2 & 1 & 2 & 1 & 3 & 1 & 4 & 1 & O1 ElTor & $\mathrm{E}$ & USA \\
\hline 51 & 1 & $6-3 / 6$ & 3 & 3 & 1 & 1 & 1 & 6 & 2 & 3 & 1 & 2 & 2 & 3 & 1 & 4 & 1 & O1 ElTor & $\mathrm{E}$ & USA \\
\hline 52 & 1 & NT330 & 4 & 3 & 1 & 2 & 2 & 3 & 2 & 2 & 1 & 1 & 2 & 3 & 5 & 5 & 1 & O139 & $\mathrm{C}$ & India \\
\hline \multirow[t]{2}{*}{53} & 2 & $\mathrm{CO} 402$ & 6 & 3 & 1 & 3 & 2 & 3 & 2 & 2 & 1 & 1 & 1 & 3 & 4 & 4 & 1 & O139 & $\mathrm{F}$ & India \\
\hline & & SO30 & 6 & 3 & 1 & 3 & 2 & 3 & 2 & 2 & 1 & 1 & 1 & 3 & 4 & 4 & 1 & O139 & $\mathrm{C}$ & India \\
\hline 54 & 1 & $\mathrm{CO} 414$ & 6 & 3 & 2 & 3 & 2 & 3 & 2 & 2 & 1 & 1 & 1 & 3 & 1 & 4 & 3 & O139 & $\mathrm{F}$ & Unknown \\
\hline 55 & 1 & NT642 & 6 & 3 & 1 & 3 & 2 & 4 & 2 & 2 & 3 & 1 & 2 & 3 & 1 & 4 & 1 & O139 & $\mathrm{C}$ & India \\
\hline 56 & 1 & BO1 & 6 & 3 & 1 & 3 & 2 & 3 & 2 & 2 & 1 & 1 & 1 & 3 & 1 & 4 & 1 & O139 & $\mathrm{F}$ & India \\
\hline 57 & 1 & ATCC14035 & 6 & 3 & 1 & 2 & 2 & 3 & 2 & 2 & 1 & 2 & 1 & 3 & 0 & 4 & 1 & O1 classical & $\mathrm{C}$ & UK \\
\hline 58 & 1 & $2030 \mathrm{H}$ & 1 & 3 & 1 & 2 & 1 & 3 & 2 & 3 & 3 & 2 & 1 & 3 & 4 & 1 & 5 & non-O1/non-O139 & $\mathrm{E}$ & USA \\
\hline 59 & 1 & NT329 & 6 & 3 & 1 & 3 & 2 & 3 & 2 & 2 & 1 & 1 & 1 & 3 & 1 & 4 & 4 & $\mathrm{O} 139$ & $\mathrm{C}$ & India \\
\hline \multirow[t]{2}{*}{60} & 2 & 25872 & 6 & 3 & 1 & 2 & 2 & 3 & 2 & 2 & 1 & 1 & 1 & 3 & 5 & 4 & 1 & non-O1/non-O139 & $\mathrm{E}$ & Unknown \\
\hline & & CO406 & 6 & 3 & 1 & 2 & 2 & 3 & 2 & 2 & 1 & 1 & 1 & 3 & 5 & 4 & 1 & $\mathrm{O} 139$ & $\mathrm{~F}$ & India \\
\hline 61 & 1 & BLO9 & 6 & 3 & 1 & 2 & 2 & 3 & 2 & 3 & 1 & 1 & 1 & 3 & 1 & 4 & 3 & O1 ElTor & $\mathrm{C}$ & Bangladesh \\
\hline 62 & 1 & MDO90 & 4 & 3 & 1 & 1 & 2 & 3 & 2 & 3 & 1 & 1 & 1 & 3 & 1 & 4 & 1 & O139 & $\mathrm{C}$ & India \\
\hline 63 & 1 & SO29 & 6 & 3 & 1 & 4 & 2 & 3 & 2 & 2 & 1 & 1 & 1 & 3 & 4 & 4 & 1 & O139 & $\mathrm{C}$ & India \\
\hline 64 & 1 & VO6 & 4 & 3 & 1 & 3 & 2 & 3 & 2 & 2 & 1 & 1 & 1 & 3 & 0 & 4 & 1 & O139 & $\mathrm{C}$ & India \\
\hline 65 & 1 & $\mathrm{BO} 2$ & 4 & 3 & 1 & 1 & 2 & 6 & 2 & 3 & 1 & 1 & 1 & 3 & 4 & 4 & 1 & O139 & $\mathrm{F}$ & India \\
\hline 66 & 1 & CO404 NT656 & 6 & 1 & 1 & 3 & 2 & 3 & 2 & 4 & 1 & 1 & 0 & 1 & 1 & 5 & 2 & O139 & $\mathrm{F}$ & India \\
\hline
\end{tabular}


Table 1 (cont.)

\begin{tabular}{|c|c|c|c|c|c|c|c|c|c|c|c|c|c|c|c|c|c|c|c|c|}
\hline \multirow[t]{2}{*}{ ET } & \multirow{2}{*}{$\begin{array}{l}\text { No. of } \\
\text { strains }\end{array}$} & \multirow{2}{*}{$\begin{array}{l}\text { Reference } \\
\text { isolates }\end{array}$} & \multicolumn{15}{|c|}{ Allele at enzyme locus } & \multirow[t]{2}{*}{ Serogroup/biotype } & \multirow[t]{2}{*}{ Source* } & \multirow[t]{2}{*}{ Country } \\
\hline & & & G6P & IDH & ALD & GP1 & $\mathrm{MDH}$ & FUM & ASD & LAP & ME & EST & $\mathrm{C} 23 \mathrm{O}$ & NSP & $\mathrm{XDH}$ & PGI & 6PG & & & \\
\hline 67 & 1 & CO417 & 6 & 3 & 1 & 3 & 2 & 3 & 2 & 2 & 1 & 1 & 1 & 3 & 5 & 4 & 1 & O1 ElTor & $\mathrm{F}$ & India \\
\hline 68 & 1 & $3 / 06 / 02$ & 4 & 2 & 1 & 1 & 1 & 3 & 2 & 5 & 1 & 1 & 1 & 3 & 1 & 4 & 1 & non-O1/non-O139 & $\mathrm{F}$ & USA \\
\hline 69 & 1 & $5-6 / 37$ & 4 & 2 & 1 & 2 & 2 & 3 & 2 & 3 & 1 & 1 & 1 & 3 & 1 & 4 & 3 & O1 classical & $\mathrm{E}$ & Tanzania \\
\hline 70 & 1 & $1196 / 78$ & 3 & 4 & 1 & 2 & 1 & 6 & 2 & 1 & 1 & 2 & 1 & 2 & 5 & 2 & 6 & O1 classical & $\mathrm{E}$ & USA \\
\hline 71 & 1 & $\mathrm{CO} 403$ & 4 & 3 & 1 & 2 & 2 & 3 & 2 & 3 & 1 & 1 & 1 & 3 & 4 & 4 & 1 & O139 & $\mathrm{F}$ & India \\
\hline 72 & 1 & $2076 / 29$ & 3 & 2 & 2 & 2 & 1 & 4 & 2 & 3 & 1 & 2 & 2 & 3 & 1 & 3 & 1 & non-O1/non-O139 & $\mathrm{E}$ & Unknown \\
\hline 73 & 1 & $3-6 / 69$ & 4 & 2 & 1 & 2 & 1 & 3 & 2 & 3 & 1 & 2 & 0 & 3 & 1 & 5 & 2 & O1 ElTor & $\mathrm{E}$ & USA \\
\hline 74 & 1 & MEX332 & 4 & 3 & 1 & 3 & 2 & 3 & 3 & 4 & 1 & 1 & 2 & 3 & 1 & 4 & 0 & O1 classical & $\mathrm{C}$ & Mexico \\
\hline 75 & 1 & NM4392 & 3 & 3 & 1 & 2 & 1 & 5 & 2 & 4 & 1 & 2 & 2 & 3 & 1 & 3 & 0 & O1 ElTor & $\mathrm{C}$ & Unknown \\
\hline 76 & 1 & 329 & 4 & 3 & 1 & 2 & 2 & 3 & 2 & 3 & 1 & 1 & 2 & 3 & 1 & 4 & 1 & O139 & $\mathrm{C}$ & Unknown \\
\hline 77 & 1 & $34-1$ & 4 & 1 & 2 & 2 & 3 & 3 & 3 & 1 & 4 & 2 & 1 & 3 & 2 & 4 & 2 & non-O1/non-O139 & $\mathrm{E}$ & Unknown \\
\hline 78 & 1 & $1-7 / 69$ & 3 & 3 & 1 & 2 & 1 & 6 & 2 & 3 & 1 & 2 & 1 & 3 & 1 & 2 & 4 & O1 ElTor & $\mathrm{E}$ & USA \\
\hline 79 & 1 & MEX445 & 3 & 4 & 1 & 2 & 1 & 2 & 1 & 1 & 2 & 1 & 1 & 3 & 4 & 4 & 1 & O1 classical & $\mathrm{C}$ & Mexico \\
\hline 80 & 1 & NM286 & 5 & 3 & 1 & 3 & 2 & 4 & 2 & 4 & 1 & 2 & 2 & 3 & 0 & 5 & 0 & O1 ElTor & $\mathrm{C}$ & India \\
\hline 81 & 1 & $653 / 36$ & 3 & 4 & 1 & 2 & 1 & 4 & 2 & 1 & 1 & 2 & 2 & 3 & 0 & 4 & 0 & O139 & $\mathrm{C}$ & India \\
\hline 82 & 1 & 25873 & 4 & 3 & 1 & 1 & 2 & 3 & 2 & 3 & 1 & 1 & 1 & 3 & 4 & 4 & 4 & non-O1/non-O139 & $\mathrm{E}$ & Unknown \\
\hline 83 & 1 & CO396 NT646 & 6 & 3 & 1 & 2 & 2 & 3 & 2 & 1 & 1 & 2 & 1 & 3 & 1 & 4 & 3 & O139 & $\mathrm{C}$ & India \\
\hline 84 & 1 & $3-6 / 3$ & 3 & 3 & 1 & 2 & 1 & 4 & 2 & 7 & 1 & 2 & 2 & 3 & 1 & 4 & 1 & non-O1/non-O139 & $\mathrm{E}$ & USA \\
\hline 85 & 1 & $6-3 / 2$ & 3 & 2 & 1 & 2 & 1 & 4 & 2 & 3 & 1 & 2 & 2 & 3 & 1 & 4 & 1 & O1 ElTor & $\mathrm{E}$ & USA \\
\hline 86 & 1 & $6-3 / 50$ & 3 & 3 & 1 & 2 & 3 & 3 & 3 & 4 & 4 & 2 & 2 & 3 & 0 & 4 & 1 & non-O1/non-O139 & $\mathrm{E}$ & USA \\
\hline 87 & 1 & NPO388 & 3 & 2 & 1 & 2 & 3 & 3 & 3 & 3 & 4 & 2 & 0 & 3 & 1 & 0 & 0 & O139 & $\mathrm{C}$ & India \\
\hline 88 & 1 & CO416 & 3 & 2 & 1 & 2 & 3 & 3 & 3 & 1 & 4 & 2 & 2 & 3 & 2 & 3 & 1 & O1 ElTor & $\mathrm{F}$ & India \\
\hline 89 & 1 & NT648 & 6 & 3 & 1 & 2 & 2 & 3 & 2 & 7 & 1 & 1 & 0 & 2 & 3 & 5 & 2 & O139 & $\mathrm{C}$ & India \\
\hline \multirow[t]{2}{*}{90} & 2 & NPO390 & 6 & 3 & 1 & 3 & 2 & 3 & 2 & 3 & 1 & 1 & 1 & 3 & 1 & 4 & 1 & O139 & $\mathrm{C}$ & India \\
\hline & & BO4 & 6 & 3 & 1 & 3 & 2 & 3 & 2 & 3 & 1 & 1 & 1 & 3 & 1 & 4 & 1 & O139 & $\mathrm{F}$ & India \\
\hline 91 & 1 & SO19 & 3 & 3 & 1 & 2 & 1 & 3 & 2 & 7 & 1 & 2 & 2 & 3 & 1 & 3 & 6 & O139 & $\mathrm{C}$ & India \\
\hline 92 & 1 & CO415 & 6 & 3 & 1 & 2 & 2 & 3 & 2 & 2 & 1 & 1 & 2 & 3 & 1 & 4 & 1 & O139 & $\mathrm{F}$ & India \\
\hline 93 & 1 & MOD084 & 6 & 3 & 1 & 2 & 2 & 3 & 2 & 3 & 1 & 1 & 2 & 3 & 0 & 4 & 1 & O139 & $\mathrm{C}$ & India \\
\hline 94 & 1 & NT638 & 6 & 3 & 1 & 3 & 2 & 3 & 2 & 2 & 1 & 1 & 2 & 3 & 1 & 4 & 1 & O139 & $\mathrm{C}$ & India \\
\hline 95 & 1 & $1074-78$ & 3 & 4 & 1 & 2 & 1 & 1 & 1 & 3 & 3 & 2 & 1 & 3 & 1 & 4 & 3 & O1 classical & $\mathrm{E}$ & USA \\
\hline 96 & 1 & CO418 & 6 & 3 & 1 & 1 & 2 & 3 & 2 & 3 & 1 & 1 & 1 & 3 & 1 & 4 & 1 & O139 & $\mathrm{F}$ & India \\
\hline \multirow[t]{2}{*}{97} & 2 & ALVC-91-0803 & 4 & 3 & 1 & 2 & 2 & 3 & 2 & 7 & 1 & 1 & 1 & 3 & 1 & 4 & 1 & O1 ElTor & $\mathrm{C}$ & Peru \\
\hline & & ALVC-91-1019 & 4 & 3 & 1 & 2 & 2 & 3 & 2 & 7 & 1 & 1 & 1 & 3 & 1 & 4 & 1 & O1 ElTor & $\mathrm{C}$ & Peru \\
\hline 98 & 1 & ALVC-92-0534 & 6 & 3 & 1 & 3 & 2 & 3 & 2 & 1 & 1 & 1 & 2 & 3 & 1 & 4 & 1 & O1 ElTor & $\mathrm{C}$ & Peru \\
\hline 99 & 1 & ALVC-93-0024 & 4 & 3 & 1 & 1 & 2 & 3 & 2 & 4 & 1 & 1 & 2 & 3 & 1 & 4 & 1 & O1 ElTor & $\mathrm{C}$ & Peru \\
\hline
\end{tabular}


Displacement of the electromorphs was expressed in terms of relative electrophoretic mobility with respect to the bromophenol blue band. Electromorphs of an enzyme were equated with alleles at the corresponding structural gene locus. Absence of enzyme activity was attributed to a null allele, and designated as 0 . Distinct combinations of alleles over the 15 loci assayed were named as electrophoretic types (ETs).

Data treatment. Genetic diversity for a locus was calculated according to Nei (1978). The probability that two isolates differ at the $j$ th locus is $h_{j}=\left(1-\Sigma p_{i j}^{2}\right) n /(n-1)$, where $p_{i j}$ is the frequency of allele $i$ at locus $j$ and $n$ is the number of isolates. The mean genetic diversity, $H$, is the arithmetic mean of $h_{j}$ for $m$ loci. Genotypic diversity was calculated as $G=1-$ $\Sigma g_{j}^{2}$, where $g_{j}$ is the frequency of the $j$ th genotype (ET). Clustering of data obtained by MLEE was performed with the PHYLIP package (Felsenstein, 1993) from a matrix of coefficients of distances by the unweighted pair-group method for arithmetic averages (UPGMA). Distance between pairs of ETs was calculated as the proportion of loci at which dissimilar electromorphs occurred. The cophenetic correlation coefficient was calculated using NTSYS-pc, version 1.80 (Rohlf, 1993). Multilocus linkage disequilibrium was estimated on the basis of the distribution of allelic mismatches between pairs of bacterial isolates among all the loci examined. The ratio of the observed variance in mismatches $\left(V_{\mathrm{o}}\right)$ to the expected variance at linkage equilibrium $\left(V_{\mathrm{E}}\right)$ provides a measure of multilocus linkage disequilibrium that can be expressed as the index of association $\left(I_{\mathrm{A}}\right) ; I_{\mathrm{A}}=\left(V_{\mathrm{O}} / V_{\mathrm{E}}\right)-1$ (Brown et al., 1980; Maynard Smith et al., 1993). For populations in linkage equilibrium, $V_{\mathrm{O}}=V_{\mathrm{E}}$ and $I_{\mathrm{A}}$ is not significantly different from zero, whereas values of $I_{\mathrm{A}}$ greater than zero indicate that recombination has been rare or absent. To determine whether $V_{\mathrm{O}}$ is significantly different from $V_{\mathrm{E}}$ in any sample, a Montecarlo procedure was generated by randomly sampling alleles, without replacement, according to their respective frequencies at each locus (Fusté et al., 1996). Computer programs written by T. S. Whittam (Selander et al., 1986) and J. G. Lorén were used to calculate $V_{\mathrm{O}}$ and $V_{\mathrm{E}}$ and to perform the Montecarlo randomization.

Estimates of the genetic differentiation between subpopulations were obtained by using Nei's genetic distance (Nei, 1972). Phylogenetic analyses were performed with the PHYLIP package by using the neighbour-joining method. The reliability of the cladograms obtained (Fig. 3) was determined by bootstrapping as follows. Gene frequencies were randomly selected, with replacement, to produce 100 replicated data sets of the same size as the original data sets. New Nei's distance matrices were then calculated and subjected to the neighbourjoining method. Comparison of the 100 bootstrapped cladograms generated was made using the Consensus program of the PHYLIP package.

\section{RESULTS}

\section{ETs and genetic diversity}

From a collection of 107 isolates of V. cholerae analysed by MLEE, 99 ETs were identified. The genotypic diversity $(G)$ for all samples was $0 \cdot 9872$. All the enzyme loci studied were polymorphic, and the number of alleles ranged from two (ALD and EST) to seven (FUM, LAP, $\mathrm{XDH}$ and $6 \mathrm{PG}$ ) (Table 2). The mean number of alleles per locus was $4 \cdot 8$. A small number of null alleles was observed (17 among the 99 ETs), distributed over 4 of the 15 enzymes assayed. Genetic diversity ranged from
0.08 for the least polymorphic loci (ALD and NSP) to 0.83 for the most polymorphic locus (LAP), with a mean genetic diversity $(H)$ of 0.50 (Table 2 ). (A comparison of genetic diversity between the different sample sets is shown in Table 5.)

\section{Genetic relationships among multilocus genotypes}

The genetic relationship among the 99 ETs is shown in Fig. 1. The cophenetic correlation coefficient of the total sample was $R=0 \cdot 81$. The shortest genetic distance observed between ETs (0.06) corresponds to a single locus difference. No significant clustering among isolates was detected according to their serogroup, biotype or country of isolation. All but six of the total ETs are represented in two major divisions in the dendrogram, designated as divisions I and II, which diverge at a genetic distance of $0 \cdot 6$. Division II is constituted by 34 ETs, most of which are environmental non-O1/nonO139 strains. In division I we have designated two subgroups: Ia, which includes a large number of environmental strains, and Ib, with a greater number of clinical strains. The third group, division III, diverges at a genetic distance of 0.65 . This is the deepest lineage found in the dendrogram and is clearly differentiated from all the other strains. This lineage is represented by six ETs $(77,12,14,87,86,88)$ without any apparent relationship between them.

Table 4 shows the 30 pairs of ETs that differ at a single enzyme locus. The loci that occur most frequently in this analysis are GP1 (seven pairs of ETs) and LAP (six pairs of ETs); none of these 30 pairs of ETs differ in the loci EST, FUM, NSP or PGI. In addition, we identified 15 pairs of ETs which are formed by strains of the same serogroup: seven pairs of O139 strains, five of nonO1/non-O139 and three of O1 ElTor isolates. In four of these cases, the pairs of ETs are represented by strains from a different country of isolation. On the other hand, the other pairs of ETs are formed by strains of different serogroups, except O1 classical.

\section{Linkage disequilibrium analysis}

Allele mismatch distribution among 99 ETs is shown in Fig. 2. Our population of $V$. cholerae presents a unimodal allele mismatch distribution, which suggests that it has a panmictic structure (Whittam, 1995). The complete set of isolates and population subsets was analysed for multilocus linkage disequilibrium (Table 5 ). The index of association $\left(I_{\mathrm{A}}\right)$ found for the total sample was $1 \cdot 25 \pm 0 \cdot 14$, which suggested that this population of $V$. cholerae presents a significant level of linkage disequilibrium. Table 5 also shows the results obtained for several population subsets studied. When we considered divisions of the dendrogram, serogroups, sources and geographical origin of the strains, all subsets showed $I_{\mathrm{A}}$ values differing significantly from zero, except division II and III, O1 classical and USA/Mexico subgroups, which exhibited $I_{\mathrm{A}}$ values of $0 \cdot 41,0 \cdot 08,0 \cdot 64$ and $0 \cdot 42$, respectively. 
Table 2. Allele frequencies and genetic diversities at 15 enzyme loci in 99 ETs of $V$. cholerae

\begin{tabular}{|c|c|c|c|c|c|c|c|c|c|c|}
\hline \multirow{2}{*}{$\begin{array}{l}\text { Enzyme } \\
\text { locus }\end{array}$} & \multirow{2}{*}{$\begin{array}{l}\text { Max. no of } \\
\text { alleles }\end{array}$} & \multicolumn{8}{|c|}{ Frequency of each allele } & \multirow[t]{2}{*}{$h^{*}$} \\
\hline & & 1 & 2 & 3 & 4 & 5 & 6 & 7 & $\mathbf{0}$ & \\
\hline G6P & 6 & $0 \cdot 010$ & $0 \cdot 010$ & $0 \cdot 354$ & $0 \cdot 343$ & $0 \cdot 010$ & $0 \cdot 273$ & & & $0 \cdot 69$ \\
\hline IDH & 4 & $0 \cdot 081$ & $0 \cdot 101$ & $0 \cdot 758$ & $0 \cdot 061$ & & & & & $0 \cdot 41$ \\
\hline ALD & 2 & $0 \cdot 960$ & $0 \cdot 040$ & & & & & & & $0 \cdot 08$ \\
\hline GP1 & 5 & $0 \cdot 202$ & $0 \cdot 586$ & $0 \cdot 192$ & $0 \cdot 010$ & $0 \cdot 010$ & & & & $0 \cdot 58$ \\
\hline $\mathrm{MDH}$ & 3 & $0 \cdot 465$ & $0 \cdot 475$ & $0 \cdot 061$ & & & & & & 0.56 \\
\hline FUM & 7 & $0 \cdot 010$ & $0 \cdot 081$ & $0 \cdot 606$ & $0 \cdot 152$ & $0 \cdot 061$ & $0 \cdot 051$ & $0 \cdot 040$ & & $0 \cdot 60$ \\
\hline ASD & 4 & $0 \cdot 121$ & 0.798 & $0 \cdot 071$ & & & & & $0 \cdot 010$ & $0 \cdot 35$ \\
\hline LAP & 7 & $0 \cdot 121$ & $0 \cdot 222$ & $0 \cdot 212$ & $0 \cdot 101$ & $0 \cdot 192$ & $0 \cdot 010$ & $0 \cdot 141$ & & $0 \cdot 83$ \\
\hline $\mathrm{ME}$ & 5 & 0.596 & $0 \cdot 121$ & $0 \cdot 222$ & $0 \cdot 051$ & $0 \cdot 010$ & & & & $0 \cdot 58$ \\
\hline EST & 2 & $0 \cdot 556$ & $0 \cdot 444$ & & & & & & & $0 \cdot 50$ \\
\hline $\mathrm{C} 23 \mathrm{O}$ & 4 & $0 \cdot 515$ & $0 \cdot 424$ & $0 \cdot 020$ & & & & & $0 \cdot 040$ & $0 \cdot 56$ \\
\hline NSP & 3 & $0 \cdot 020$ & $0 \cdot 020$ & $0 \cdot 960$ & & & & & & $0 \cdot 08$ \\
\hline $\mathrm{XDH}$ & 7 & $0 \cdot 636$ & $0 \cdot 020$ & $0 \cdot 010$ & $0 \cdot 202$ & $0 \cdot 061$ & $0 \cdot 010$ & & $0 \cdot 061$ & $0 \cdot 55$ \\
\hline PGI & 6 & $0 \cdot 010$ & $0 \cdot 111$ & $0 \cdot 172$ & $0 \cdot 647$ & $0 \cdot 051$ & & & $0 \cdot 010$ & $0 \cdot 54$ \\
\hline \multirow[t]{2}{*}{$6 \mathrm{PG}$} & 7 & 0.626 & $0 \cdot 051$ & $0 \cdot 111$ & $0 \cdot 040$ & $0 \cdot 091$ & $0 \cdot 030$ & & $0 \cdot 051$ & 0.59 \\
\hline & & & & & & \multicolumn{4}{|c|}{ Mean genetic diversity, $H$} & $0 \cdot 50$ \\
\hline
\end{tabular}

$* h$, genetic diversity.

\section{Genetic distances within population subgroups}

The clustering of strains considering serogroups and geographical origin from values of genetic distances between population subgroups is shown in Fig. 3. The cladogram of the geographical subpopulations showed that the strains from the USA, Brazil and Mexico were more genetically related to each other than to the isolates of $V$. cholerae from India and Peru. On the other hand, the cladogram of the serogroup/biotype subpopulations confirmed that the O1 ElTor and O139 strains were genetically more related to each other than to other serogroups.

\section{DISCUSSION}

Nowadays $V$. cholerae is a well-defined species based on biochemical tests and DNA homology studies (Baumann et al., 1984), though it is a highly heterogeneous group with respect to its pathogenic potential: only two out of the nearly 200 serogroups defined at present, O1 and O139, have been associated with epidemics (Kaper et al., 1995). Therefore many aspects of the ecology of $V$. cholerae and its relationship to the pathogenesis and epidemiology of cholera remain unknown (Faruque et al., 1998).

Bacterial population genetics is the study of the natural variability of bacterial populations and has led to the formulation of theories to account for this diversity (Maynard Smith et al., 1993). Classical and molecular methods have continously been used to study the population diversity of $V$. cholerae and have been extensively applied to characterize different serogroups and biotypes (Baumann et al., 1984), ribotypes (Karaolis et al., 1994), RAPD fingerprint types (Rivera et al., 1995) and insertion sequence fingerprint types (Bik et al., 1996). These methods have shown a considerable amount of variation in $V$. cholerae. MLEE constitutes the classical methodology in the study of bacterial population genetics (Selander et al., 1986). By using MLEE data we can obtain estimates of genetic and genotypic diversity and estimates of the frequency of recombination in natural populations. These aspects of $V$. cholerae population biology are of great importance to molecular epidemiological studies of cholera.

Previous MLEE studies with $V$. cholerae have shown a limited genetic diversity among toxigenic strains of this bacterium. Pathogenic isolates from various sources all showed identical electrophoretic profiles or differed in only a few loci (Salles \& Momen, 1991; Wachsmuth et al., 1993; Evins et al., 1995). Some authors indicate that the sixth-pandemic, the seventh-pandemic and the US Gulf isolates are three independent clones (Kaper et al., 1982; Waschmuth et al., 1993; Karaolis et al., 1994, 1995; Evins et al., 1995). In a recent study, it has been postulated that all strains of the O139 serogroup belong to a unique ET; similarly the toxigenic O1 ElTor isolates cluster in only three ETs (Beltrán et al., 1999).

Our results show that when MLEE methods were applied to a large collection of isolates of diverse origin including serogroup O1 (classical and ElTor biotypes), O139 and non-O1/non-O139 strains, the different $V$. cholerae populations showed a high degree of genetic variation. The number of ETs found in our work does 


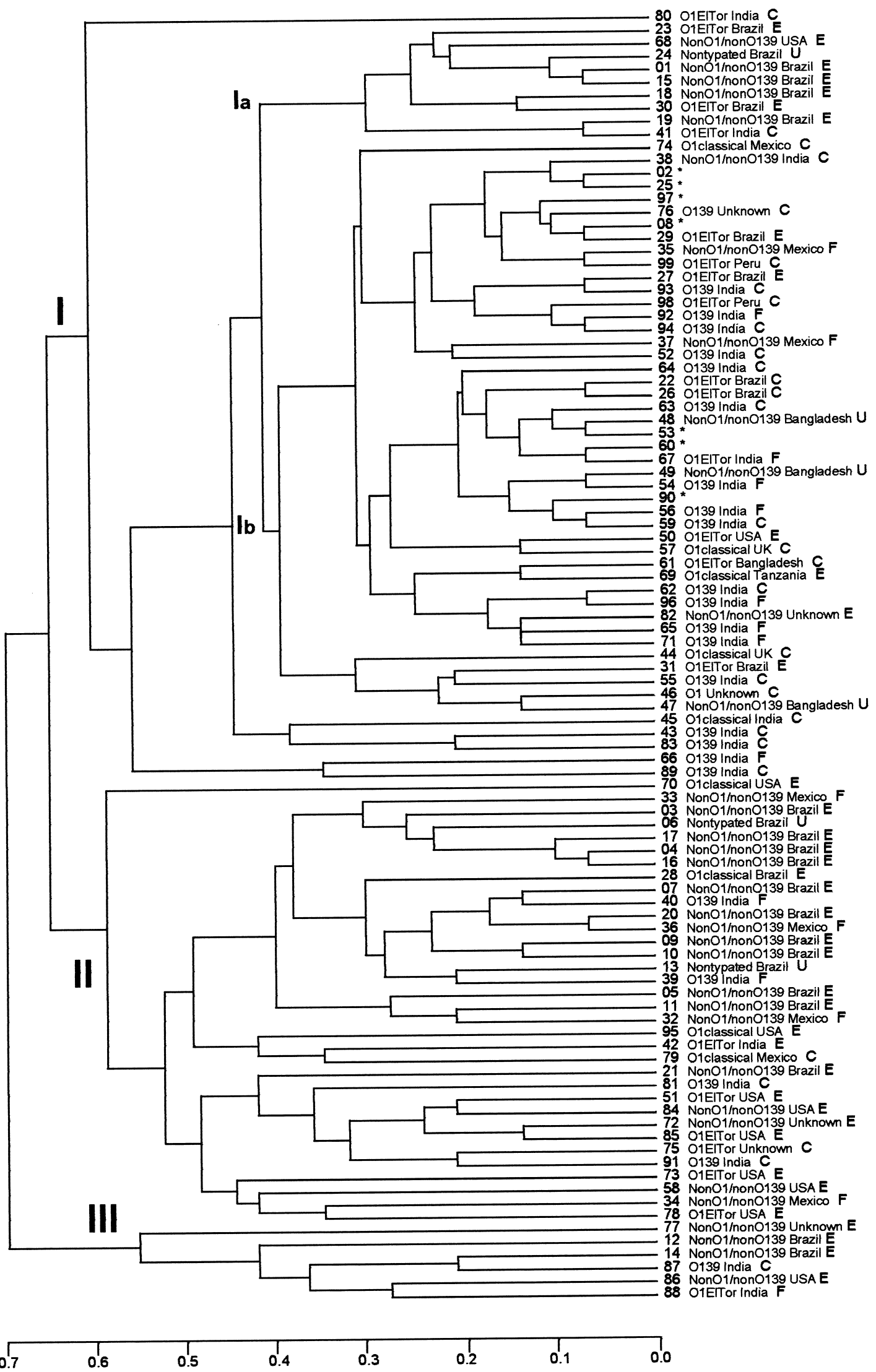

Fig. 1. For legend see facing page. 
Table 3. Groups of strains with identical genotype

\begin{tabular}{|c|c|c|c|c|c|}
\hline ET & No. of strains & Reference isolates & Serogroup/biotype & Source* & Country \\
\hline \multirow[t]{2}{*}{2} & 2 & TM34162-77 & non-O1/non-O139 & $\mathrm{E}$ & Brazil \\
\hline & & TM9024-79 & non-O1/non-O139 & E & Brazil \\
\hline \multirow[t]{3}{*}{8} & 3 & TM48733-82 & non-O1/non-O139 & $\mathrm{E}$ & Brazil \\
\hline & & TM11079-80 & O1 ElTor & $\mathrm{E}$ & Brazil \\
\hline & & CO484 & non-O1/non-O139 & E & India \\
\hline \multirow[t]{2}{*}{25} & 2 & TM207832-78 & O1 ElTor & E & Brazil \\
\hline & & ALVC-92-0344 & O1 ElTor & $\mathrm{C}$ & Peru \\
\hline \multirow[t]{2}{*}{53} & 2 & $\mathrm{CO} 402$ & O139 & $\mathrm{F}$ & India \\
\hline & & SO30 & O139 & $\mathrm{C}$ & India \\
\hline \multirow[t]{2}{*}{60} & 2 & 25872 & non-O1/non-O139 & $\mathrm{E}$ & Unknown \\
\hline & & CO406 & O139 & $\mathrm{F}$ & India \\
\hline \multirow[t]{2}{*}{90} & 2 & NPO390 & O139 & $\mathrm{C}$ & India \\
\hline & & $\mathrm{BO} 4$ & O139 & $\mathrm{F}$ & India \\
\hline \multirow[t]{2}{*}{97} & 2 & ALVC-91-0803 & O1 ElTor & $\mathrm{C}$ & Peru \\
\hline & & ALVC-91-1019 & O1 ElTor & $\mathrm{C}$ & Peru \\
\hline
\end{tabular}

*C, clinical; E, environmental; F, faecal.

not coincide with data previously published (Salles \& Momen, 1991; Wachsmuth et al., 1993; Evins et al., 1995; Beltrán et al., 1999). From 107 isolates analysed, 99 ETs were found, 84 containing a single strain, six containing two strains and only one containing three strains. Previous studies described a more limited diversity of $V$. cholerae populations, with most isolates clustering in two or three ETs with minimal differences between them, especially when toxigenic strains were included (Salles \& Momen, 1991; Wachsmuth et al., 1993; Evins et al., 1995). The estimate for the mean genetic diversity per locus of the total 99 ETs $(H=0.50)$ in our study is greater than other values reported for $V$. cholerae (Chen et al., 1991; Salles \& Momen, 1991; Wachsmuth et al., 1993; Evins et al., 1995; Beltrán et al., 1999). Likewise, the mean number of alleles per locus $(4 \cdot 8)$, and the genotypic diversity (0.9872) were higher than those given in similar studies, with the exception of Beltrán et al. (1999), who reported a value of 9.5 alleles per locus as an average. Also, the work of Beltrán et al. (1999) differed in the number of strains that fell into the same ET.

Differences in the serogroup, geographical origin and year of isolation could explain this diversity. Another factor that may influence the results is the methodology used; some previous studies used starch as a matrix for the gels, whose resolution could be distinct from that of polyacrylamide (Wachsmuth et al., 1993; Evins et al., 1995 ; Beltrán et al., 1999). Finally, the number and type of enzymes studied are different; most of them are monomorphic and only a few contribute to the genetic diversity. However, in our work all the enzymes were polymorphic with a considerable genetic diversity, thus hampering comparisons between studies.
The dendrogram obtained in the present study shows no association between isolates with regard to serogroup, biotype or geographical origin. The same serogroup is present in several lineages and does not cluster separately from the others (Fig. 1). Similar results were obtained by Beltrán et al. (1999), who showed that strains of the same serogroup may belong to two or more divergent ET lineages. Division II has more non-O1/non-O139 strains than other groups. On the other hand, most of the O139 serogroup strains clustered in division I ( 24 of 29 isolates), while other serogroups seem to be randomly distributed. With regard to the source of the strains studied, division II seems to contain most of the environmental strains, while clinical isolates predominate in the subgroup Ib. Although this clustering did not coincide with previous studies, the value of the cophenetic correlation coefficient obtained $(R=0 \cdot 81)$ falls into the range $(0.74-0.90)$ of most frequently occurring cophenetic correlations reported by Sneath \& Sokal (1973).

Unimodal allele mismatch distribution (Fig. 2) and the shape of the dendrogram (Fig. 1) are typical of a panmictic population (Whittam, 1995). However, evidence for clonal proliferation is provided by the multilocus linkage disequilibrium calculations, which reveal a significant level of association between alleles when the whole population sample is analysed. Values of $I_{\mathrm{A}}$ among all ETs indicated that there is a nonrandom distribution of alleles, which is clear evidence of a clonal population structure, with a significant degree of linkage disequilibrium $I_{\mathrm{A}}=1 \cdot 25 \pm 0 \cdot 14$ (no significant differences were obtained when we considered strains or ETs). Nevertheless, when we analysed data subsets corresponding to divisions of the dendrogram, sero-

Fig. 1. Dendrogram constructed by the UPGMA method, showing genetic relationships among 99 ETs of $V$. cholerae strains. The sources of the strains are indicated by the letters C (clinical), E (environmental), $F$ (faecal) and $U$ (unknown). Asterisks (*) denote ETs that contain more than one strain (see Table 3). The scale indicates genetic distance. 
Table 4. ETs that differ at a single locus

\begin{tabular}{|c|c|c|c|c|c|c|c|}
\hline ET & Serogroup & $\begin{array}{c}\text { Country of } \\
\text { isolation }\end{array}$ & Locus & ET & Serogroup & $\begin{array}{c}\text { Country of } \\
\text { isolation }\end{array}$ & Locus \\
\hline 1 & non-O1/non-O139 & Brazil & $\mathrm{ME}$ & 29 & O1 ElTor & Brazil & $\mathrm{C} 23 \mathrm{O}$ \\
\hline 15 & non-O1/non-O139 & Brazil & $\mathrm{ME}$ & 97 & O1 ElTor & Peru & $\mathrm{C} 23 \mathrm{O}$ \\
\hline 1 & non-O1/non-O139 & Brazil & IDH & 35 & non-O1/non-O139 & Mexico & LAP \\
\hline 24 & Unknown & Brazil & IDH & 99 & O1 ElTor & Peru & LAP \\
\hline 2 & non-O1/non-O139 & Brazil & $\mathrm{MDH}$ & 48 & non-O1/non-O139 & Bangladesh & $\mathrm{C} 23 \mathrm{O}$ \\
\hline \multirow[t]{2}{*}{25} & $\begin{array}{l}\text { O1 ElTor } \\
\text { O1 ElTor }\end{array}$ & $\begin{array}{l}\text { Brazil } \\
\text { Peru }\end{array}$ & $\begin{array}{l}\mathrm{MDH} \\
\mathrm{MDH}\end{array}$ & 53 & O139 & India & $\mathrm{C} 23 \mathrm{O}$ \\
\hline & & & & 48 & non-O1/non-O139 & Bangladesh & $\mathrm{XDH}$ \\
\hline 2 & non-O1/non-O139 & Brazil & IDH & 94 & O139 & India & $\mathrm{XDH}$ \\
\hline \multirow[t]{2}{*}{38} & non-O1/non-O139 & India & IDH & & & & \\
\hline & & & & 49 & non-O1/non-O139 & Bangladesh & $6 \mathrm{PG}$ \\
\hline 4 & non-O1/non-O139 & Brazil & $6 \mathrm{PG}$ & 54 & O139 & Unknown & $6 \mathrm{PG}$ \\
\hline \multirow[t]{2}{*}{16} & non-O1/non-O139 & Brazil & $6 \mathrm{PG}$ & & & & \\
\hline & & & & 49 & non-O1/non-O139 & Bangladesh & ALD \\
\hline 4 & non-O1/non-O139 & Brazil & GP1 & 59 & O139 & India & ALD \\
\hline \multirow[t]{2}{*}{17} & non-O1/non-O139 & Brazil & GP1 & & & & \\
\hline & & & & 53 & O139 & India & $\mathrm{XDH}$ \\
\hline \multirow[t]{3}{*}{8} & non-O1/non-O139 & Brazil & GP1 & 56 & O139 & India & $\mathrm{XDH}$ \\
\hline & non-O1/non-O139 & India & GP1 & 67 & O1 ElTor & India & $\mathrm{XDH}$ \\
\hline & O1 ElTor & Brazil & GP1 & & & & \\
\hline \multirow[t]{2}{*}{29} & O1 ElTor & Brazil & GP1 & 53 & O139 & India & GP1 \\
\hline & & & & 63 & O139 & India & GP1 \\
\hline 19 & non-O1/non-O139 & Brazil & LAP & & & & \\
\hline \multirow[t]{2}{*}{41} & O1 ElTor & India & LAP & 56 & O139 & India & $6 \mathrm{PG}$ \\
\hline & & & & 59 & O139 & India & $6 \mathrm{PG}$ \\
\hline 20 & non-O1/non-O139 & Brazil & ASD & & & & \\
\hline \multirow[t]{2}{*}{36} & non-O1/non-O139 & Mexico & ASD & 56 & O139 & India & LAP \\
\hline & & & & 90 & O139 & India & LAP \\
\hline 22 & O1 ElTor & Brazil & $6 \mathrm{PG}$ & & & & \\
\hline \multirow[t]{2}{*}{26} & O1 ElTor & Brazil & $6 \mathrm{PG}$ & 56 & O139 & India & $\mathrm{C} 23 \mathrm{O}$ \\
\hline & & & & 94 & O139 & India & $\mathrm{C} 23 \mathrm{O}$ \\
\hline 22 & O1 ElTor & Brazil & LAP & & & & \\
\hline \multirow[t]{3}{*}{53} & O139 & India & LAP & 60 & non-O1/non-O139 & Unknown & GP1 \\
\hline & O139 & India & LAP & & O139 & India & GP1 \\
\hline & & & & 67 & O1 ElTor & India & GP1 \\
\hline \multirow[t]{2}{*}{25} & O1 ElTor & Brazil & LAP & & & & \\
\hline & O1 ElTor & Peru & LAP & 62 & O139 & India & G6P \\
\hline 29 & O1 ElTor & Brazil & LAP & 96 & O139 & India & G6P \\
\hline \multirow[t]{2}{*}{76} & O139 & Unknown & LAP & & & & \\
\hline & & & & 90 & O139 & India & GP1 \\
\hline \multirow[t]{2}{*}{25} & O1 ElTor & Brazil & GP1 & 96 & O139 & India & GP1 \\
\hline & O1 ElTor & Peru & GP1 & & & & \\
\hline \multirow[t]{2}{*}{99} & O1 ElTor & Peru & GP1 & 92 & O139 & India & GP1 \\
\hline & & & & 94 & O139 & India & GP1 \\
\hline 27 & O1 ElTor & Brazil & $\mathrm{XDH}$ & & & & \\
\hline \multirow[t]{2}{*}{93} & O139 & India & $\mathrm{XDH}$ & 94 & O139 & India & LAP \\
\hline & & & & 98 & O1 ElTor & Peru & LAP \\
\hline
\end{tabular}

groups or geographical origin, some of them (divisions II, III, O1 classical and USA/Mexico strains) showed $I_{\mathrm{A}}$ values less than one $(0.41,0.08,0.64$ and 0.42 , respectively). The $V_{\mathrm{O}}$ values of these subgroups were also within the $95 \%$ confidence limits of $V_{\mathrm{E}}$ and within the maximum and minimum values of the variance obtained by the Montecarlo procedure. However, $I_{\mathrm{A}}$ values corresponding to the division III and the O1 classical subgroup should be taken cautiously because of the low number of ETs in these groups (six and nine ETs, respectively). These results are partially concordant with those obtained by Beltrán et al. (1999), who found 


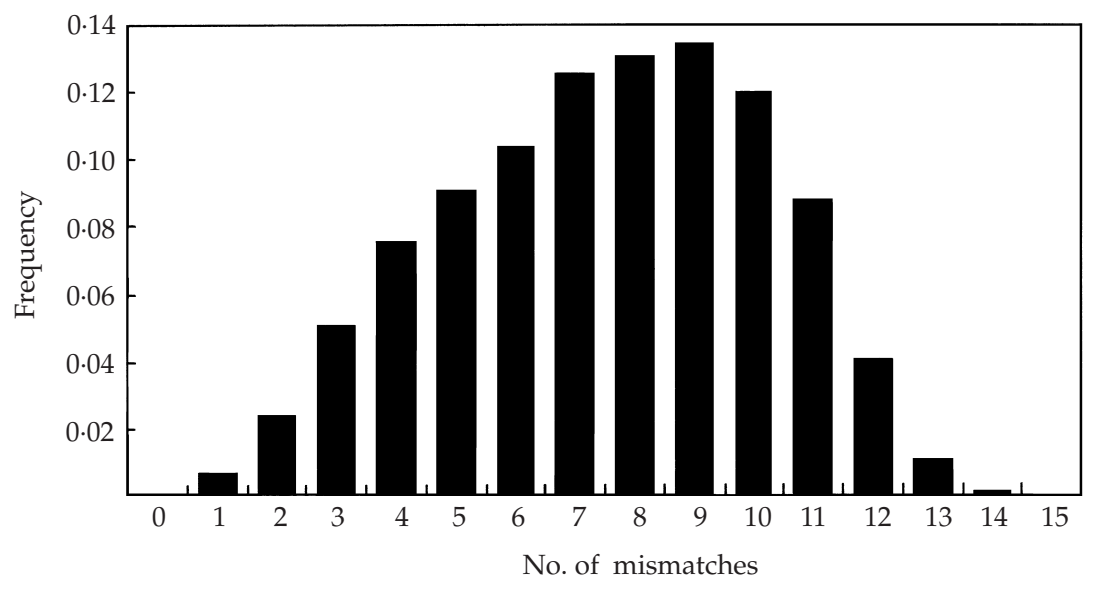

Fig. 2. Allele mismatch distribution among 99 ETs of the total sample studied.

Table 5. Multilocus linkage disequilibrium analysis of $V$. cholerae

\begin{tabular}{|c|c|c|c|c|c|c|c|c|c|}
\hline & $\begin{array}{l}\text { No. of } \\
\text { ETs }\end{array}$ & $\begin{array}{c}\text { Mean no. of } \\
\text { alleles per } \\
\text { locus }\end{array}$ & $H$ & $V_{\mathrm{O}}$ & $V_{\mathrm{E}}$ & $\begin{array}{l}95 \% \text { confidence } \\
\text { limits of } V_{\mathrm{E}}^{*}\end{array}$ & $I_{\mathrm{A}} \dagger$ & $\begin{array}{l}\text { Montecarlo } \\
V \text { minimum }\end{array}$ & $\begin{array}{c}\text { Randomization } \\
V \text { maximum }\end{array}$ \\
\hline Total 107 isolates & 99 & $4 \cdot 80$ & $0 \cdot 50$ & $7 \cdot 13$ & $3 \cdot 17$ & $2 \cdot 29-4 \cdot 04$ & $1 \cdot 25 \pm 0 \cdot 14$ & $2 \cdot 54$ & $3 \cdot 89$ \\
\hline \multicolumn{10}{|l|}{ Dendrogram } \\
\hline Division I & 59 & $3 \cdot 47$ & $0 \cdot 35$ & $3 \cdot 91$ & $2 \cdot 62$ & $1 \cdot 67-3 \cdot 56$ & $0 \cdot 49 \pm 0 \cdot 18$ & $1 \cdot 87$ & $3 \cdot 77$ \\
\hline Division II & 34 & $3 \cdot 73$ & $0 \cdot 44$ & $3 \cdot 77$ & $2 \cdot 67$ & $1 \cdot 41-3 \cdot 92$ & $0 \cdot 41 \pm 0 \cdot 24$ & $1 \cdot 78$ & $3 \cdot 88$ \\
\hline Division III & 6 & $2 \cdot 33$ & $0 \cdot 40$ & $2 \cdot 03$ & $1 \cdot 88$ & $0 \cdot 24-3.99$ & $0.08 \pm 0.56$ & $0 \cdot 27$ & $7 \cdot 52$ \\
\hline \multicolumn{10}{|l|}{ Serogroup/biotype $\neq$} \\
\hline $\mathrm{O} 1$ & 35 & $4 \cdot 00$ & $0 \cdot 49$ & $6 \cdot 54$ & $3 \cdot 04$ & $1 \cdot 63-4 \cdot 44$ & $1 \cdot 15 \pm 0 \cdot 23$ & $2 \cdot 15$ & $4 \cdot 35$ \\
\hline O1 ElTor & 24 & $3 \cdot 60$ & $0 \cdot 45$ & $7 \cdot 01$ & $2 \cdot 94$ & $1 \cdot 29-4 \cdot 57$ & $1 \cdot 39 \pm 0 \cdot 28$ & $1 \cdot 74$ & $5 \cdot 03$ \\
\hline O1 classical & 9 & $3 \cdot 33$ & $0 \cdot 57$ & $4 \cdot 35$ & $2 \cdot 65$ & $0 \cdot 20-5 \cdot 09$ & $0 \cdot 64 \pm 0 \cdot 46$ & $0 \cdot 99$ & $7 \cdot 56$ \\
\hline Non-O1/non-O139 & 37 & $4 \cdot 00$ & $0 \cdot 51$ & $6 \cdot 72$ & $3 \cdot 20$ & $1 \cdot 75-4 \cdot 64$ & $1 \cdot 10 \pm 0 \cdot 23$ & $2 \cdot 28$ & $4 \cdot 68$ \\
\hline O139 & 26 & $3 \cdot 53$ & $0 \cdot 40$ & $8 \cdot 05$ & $2 \cdot 94$ & $1 \cdot 34-4 \cdot 52$ & $1 \cdot 74 \pm 0 \cdot 27$ & $1 \cdot 51$ & $5 \cdot 09$ \\
\hline \multicolumn{10}{|l|}{$\begin{array}{c}\text { Country of } \\
\text { isolation } \neq\end{array}$} \\
\hline America $\$$ & 54 & $4 \cdot 26$ & $0 \cdot 49$ & $6 \cdot 37$ & $3 \cdot 10$ & $1 \cdot 94-4 \cdot 25$ & $1 \cdot 05 \pm 0 \cdot 19$ & $2 \cdot 28$ & $4 \cdot 09$ \\
\hline Brazil & 31 & $3 \cdot 53$ & $0 \cdot 49$ & $7 \cdot 82$ & $3 \cdot 01$ & $1 \cdot 53-4 \cdot 49$ & $1 \cdot 59 \pm 0 \cdot 24$ & $2 \cdot 14$ & $4 \cdot 25$ \\
\hline USA/Mexico & 20 & $3 \cdot 86$ & $0 \cdot 51$ & $4 \cdot 49$ & $3 \cdot 15$ & $1 \cdot 22-5 \cdot 08$ & $0 \cdot 42 \pm 0 \cdot 31$ & $1 \cdot 71$ & $5 \cdot 83$ \\
\hline India & 32 & $4 \cdot 06$ & $0 \cdot 46$ & $8 \cdot 74$ & $3 \cdot 05$ & $1 \cdot 57-4.53$ & $1 \cdot 86 \pm 0 \cdot 24$ & $1 \cdot 74$ & $4 \cdot 61$ \\
\hline \multicolumn{10}{|l|}{ Source $\neq$} \\
\hline Environmental & 47 & $4 \cdot 33$ & 0.52 & $6 \cdot 17$ & $3 \cdot 16$ & $1 \cdot 89-4 \cdot 42$ & $0 \cdot 95 \pm 0 \cdot 19$ & $2 \cdot 38$ & $4 \cdot 43$ \\
\hline $\mathrm{F}$ & 22 & $3 \cdot 53$ & $0 \cdot 48$ & $10 \cdot 16$ & $3 \cdot 27$ & $1 \cdot 35-5 \cdot 18$ & $2 \cdot 10 \pm 0 \cdot 29$ & $1 \cdot 84$ & $5 \cdot 96$ \\
\hline $\mathrm{C}$ & 31 & $3 \cdot 67$ & $0 \cdot 42$ & $6 \cdot 17$ & $2 \cdot 96$ & $1 \cdot 50-4 \cdot 42$ & $1 \cdot 08 \pm 0.25$ & $1 \cdot 75$ & $4 \cdot 63$ \\
\hline
\end{tabular}

* Calculated according to Brown et al. (1980).

† Index of association \pm SD.

¥ The same ET could be represented in various subgroups when it includes strains of diverse origin, source, serogroup or biotype. See Tables 1 and 3 .

Considering isolates from Brazil, Mexico, Peru and USA together.

$I_{\mathrm{A}}$ values quite similar to ours $(1 \cdot 248 \pm 0 \cdot 083)$ for the whole population, and $I_{\mathrm{A}}$ values close to zero when they analysed population subgroups. Therefore, our results do not rule out the possibility that the population of $V$. cholerae studied has a clonal structure, nor do they exclude recombination. We believe that this population has a clonal structure which has not been broken by genetic recombination. Another possibility is to consider that the population has an epidemic structure (Maynard Smith et al., 1993), in which strains of different origin would coexist with others of identical origin corresponding to an outbreak of disease from a single person in a specific geographical area (e.g. in July, 1994, the massive outbreak of O1 ElTor $V$. cholerae among 


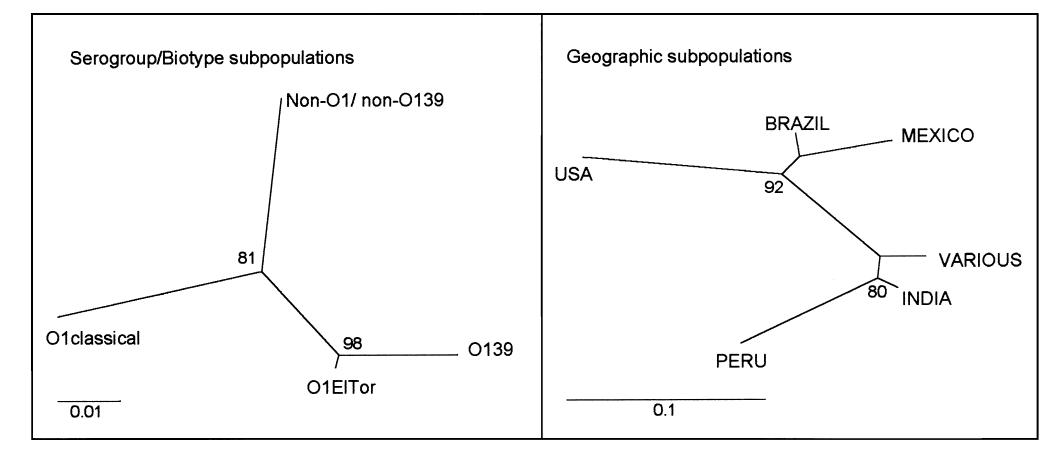

Fig. 3. Unrooted phylogenetic trees of
different subpopulations from the total
sample generated by the neighbour-joining
method of clustering of Nei's distances. The
bootstrap values for nodes are presented for
only those clusters of subpopulations which
occurred more than $80 \%$ of the time. The
scale bars indicate genetic distance.

O1 ElTor strains

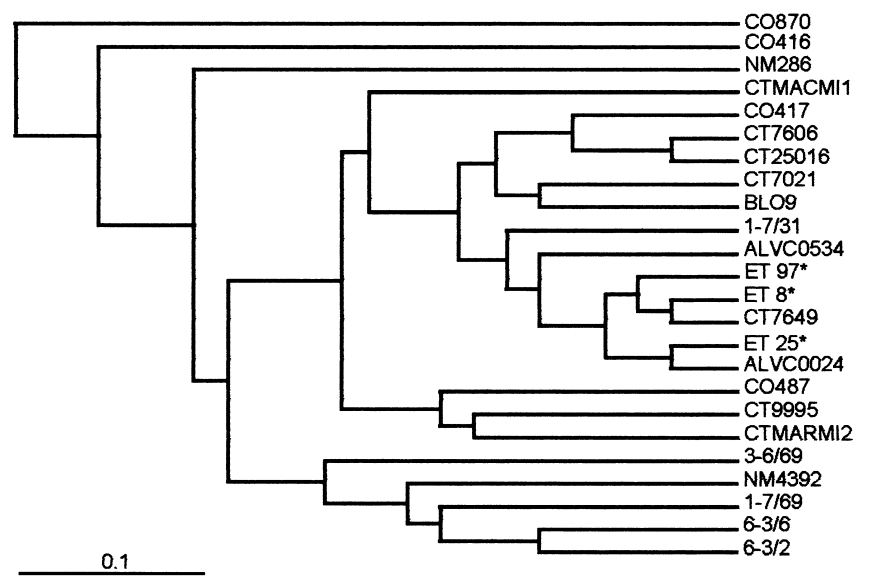

O139 strains

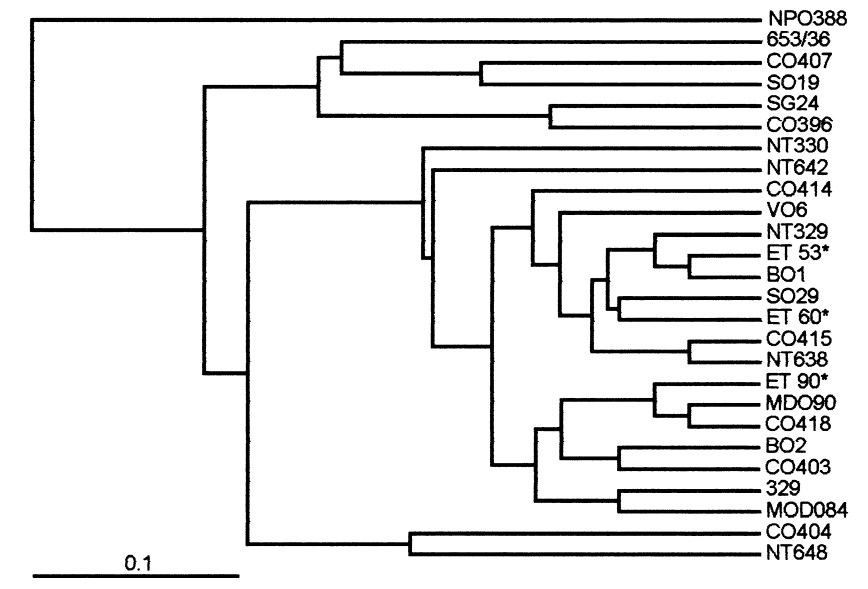

Fig. 4. Comparison of the genetic diversity of two subpopulations of the total sample, O1 ElTor and O139. Asterisks (*) denote ETs that contain more than one strain (see Table 3). The scale bars indicate genetic distance.

Rwandan refugees in Goma, Zaire: Sanchez \& Taylor, 1997).

The analysis of the genetic distances for isolates belonging to the six subpopulations that we could establish on the basis of the country of isolation (Fig. 3), showed that strains from Peru cluster in the same group as those isolated from India. This result is fully concordant with the origin of Peru's strains previously determined by Wachsmuth et al. (1993). In the same context, we might consider the results obtained with strains isolated in USA and Mexico. USA strains are longer established and remotely related with Mexico's isolates, as Wachsmuth et al. (1993) pointed out.

If we consider population subsets referring to serogroup/ biotype, there is also a concordance with previous references in relation to the origin of O1 and O139 serogroups (Bik et al., 1995; Stroeher et al., 1997). From the analysis of the genetic distances between populations it might be deduced that V. cholerae O1 ElTor and O139 originated from a unique splitting event (Fig. 3) and consequently, O139 and O1 ElTor might have gained a similar diversity $(H=0 \cdot 40$ and $H=0 \cdot 45$, respectively). Indeed, looking at Fig. 4, we can see that O139 subpopulation strains were distributed in different ETs in the same way as those of O1 ElTor. Nonetheless, the slight differences in the genetic diversity can easily be explained if we consider the geographical origin of the two sets of strains. O139 are all Indian isolates, whereas O1 ElTor were isolated in several countries (Table 1).

There are two possible explanations for the diversity found among O139. First, the dissociation might have happened a long time ago and consequently both populations have been accumulating diversity lengthwise. Second, the split might have happened recently, but several recombination events have taken place in a diverse genetic background. Neither of these hypotheses agrees with the idea of a unique ET supported by Popovic et al. (1995) and Beltrán et al. (1999). However, they would explain the diversity we observed in the O139 population.

Other population studies based on the analysis of restriction fragment length polymorphisms in genes for conserved rRNA and cholera toxin $(\operatorname{ctx} A)$ or in DNA sequences flanking these genes revealed four different ribotypes and four different $c t x$ genotypes among 93 strains of V. cholerae O139 studied (Faruque et al., 1997b). These results agree with the idea that strains belonging to the O139 serogroup may have emerged from similar serotype-specific genetic changes in more than one progenitor strain of $V$. cholerae. Considering 
this background, it is hard to believe that all the $\mathrm{O} 139$ strains could belong to a unique ET. Results obtained in our work are in agreement with the hypothesis of a more diverse origin of these strains, a conclusion that can also be reached from ribotyping analysis.

Data from the sequences of some housekeeping genes of $V$. cholerae showed a high degree of similarity when the different strains were compared, especially in clinical isolates. Karaolis et al. (1995) determined the DNA sequences of the asd (aspartate semialdehyde dehydrogenase) genes from 45 isolates of $V$. cholerae, which included five O139 isolates. Byun et al. (1999) sequenced the $m d h$ (malate dehydrogenase) and $b y l A$ (haemolysin A) genes from environmental and pathogenic strains of $V$. cholerae, including seven strains of the O139 serogroup. Both groups of authors found a high degree of similarity among the pathogenic isolates, suggesting that they are very closely related. These results may appear to disagree with the high diversity found in our work. This contradiction, however, is only apparent. Our results show that $m d h$ and asd presented a low genetic diversity within the O139 isolates studied $(m d h$, $h=0.32 ;$ asd, $h=0.07)$. Moreover, the number of O139 strains studied by these authors is low (in our work we studied 29 O139 isolates). Recently, Jiang et al. (2000) published a study applying the AFLP method to a collection of clinical and environmental isolates of $V$. cholerae, which supports the idea that pathogenic $V$. cholerae strains have evolved from multiple independent sources like environmental O1 or non-O1 strains. We believe that more extensive areas of the bacterial chromosome should be analysed (as in the case of MLEE) in order to reach a reasonable conclusion about the likely origin of a bacterial population.

The persistence of $V$. cholerae in the environment, for months and probably years, is facilitated by its ability to enter a viable nonculturable state in which its nutrient and oxygen requirements are much decreased (Ravel et al., 1995). It has also been described that V. cholerae can bind to chitin in crustacean shells, and colonize the surfaces of algae, phytoplankton, copepods and the roots of aquatic plants such as water hyacinth. One scenario to explain our findings is that during interepidemics $V$. cholerae populations might be associated with an ecological reservoir. We can considerer that all $V$. cholerae cells constitute a metapopulation integrated by multiple ecological populations. Previous studies have shown that bacterial recombination is too rare to prevent neutral sequence divergence between distinct ecological populations. Moreover, the episodes of periodic selection that purge diversity operate within populations and do not prevent their divergence (Young, 1989). In their reservoir V. cholerae clones could diverge from each other. Because the genes for the major virulence factors can be acquired horizontally, we can postulate that each V. cholerae cell would have the same probability of being transformed into a toxigenic strain (Beltrán et al., 1999). In the next epidemic episode, some unknown environmental factors might trigger an explosive multiplication of $V$. cholerae populations outside this reservoir (Epstein et al., 1993; Harvell et al., 1999). This global population would be formed by bacteria from various local populations and include a diversity of toxigenic clones that potentially could infect humans.

\section{ACKNOWLEDGEMENTS}

We are grateful to Dr R. Montilla for providing strains for this study and for his helpful comments. We are indebted to Dr J. Palomar for his help in setting up the MLEE technique. We also thank G. B. Nair, M. A. R. Chowdhury and M. Talledo for kindly supplying isolates of $V$. cholerae.

M. Farfán is the recipient of the grant 'Formació en la Recerca i Docència per a alumnes de tercer cicle' from the University of Barcelona. This work was supported by a grant from the Vicerectorat de Recerca of the University of Barcelona.

\section{REFERENCES}

Albert, M. J., Siddique, A. K., Islam, M. S., Faruque, A. S. G., Ansaruzzaman, M., Faruque, S. M. \& Sack, R. B. (1993). Large outbreak of clinical cholera due to Vibrio cholerae non-O1 in Bangladesh. Lancet 341, 704.

Baumann, P., Furniss, A. L. \& Lee, J. V. (1984). Genus I. Vibrio. In Bergey's Manual of Systematic Bacteriology, vol. 1, pp. 518-538. Edited by N. R. Kreig \& J. G. Holt. Baltimore: Williams \& Wilkins.

Beltrán, P., Delgado, G., Navarro, A., Trujillo, F., Selander, R. K. \& Cravioto, A. (1999). Genetic diversity and population structure of Vibrio cholerae. J Clin Microbiol 37, 581-590.

Bik, E. M., Bunschoten, A. E., Gouw, R. D. \& Mooi, F. R. (1995). Genesis of the novel epidemic Vibrio cholerae O139 strain: evidence for horizontal transfer of genes involved in polysaccharide synthesis. EMBO J 14, 209-216.

Bik, E. M., Gouw, R. D. \& Mooi, F. R. (1996). DNA fingerprinting of Vibrio cholerae strains with a novel insertion sequence element: a tool to identify epidemic strains. J Clin Microbiol 34, 1453-1461.

Blake, P. A. (1994). Historical perspectives on pandemic cholera. In Vibrio cholerae and Cholera: Molecular to Global Perspectives, pp. 293-295. Edited by I. K. Wachsmuth, P. A. Blake \& O. Olsvik. Washington, DC: American Society for Microbiology.

Brown, A. D., Feldman, M. W. \& Nevo, E. (1980). Multilocus structure of natural populations of Hordeum spontaneum. Genetics 96, 523-536.

Byun, R., Elbourne, L. D., Lan, R. \& Reeves, P. R. (1999). Evolutionary relationships of pathogenic clones of Vibrio cholerae by sequence analysis of four housekeeping genes. Infect Immun 67, 1116-1124.

Chen, F., Evins, G. M., Cook, W. L., Almeida, R., Hargrett-Bean, N. \& Wachsmuth, K. (1991). Genetic diversity among toxigenic and nontoxigenic Vibrio cholerae O1 isolated from the Western Hemisphere. Epidemiol Infect 107, 225-233.

Colwell, R. R. (1996). Global climate and infectious disease: the cholera paradigm. Science 274, 2025-2031.

Colwell, R. R. \& Huq, A. (1994). Vibrios in the environment: viable but nonculturable Vibrio cholerae. In Vibrio cholerae and Cholera: Molecular to Global Perspectives, pp. 117-133. Edited by I. K. Wachsmuth, P. A. Blake \& O. Olsvik. Washington, DC: American Society for Microbiology.

Epstein, P. R., Ford, T. E. \& Colwell, R. R. (1993). Marine ecosystems. Lancet 342, 1216-1219. 
Evins, G. M., Cameron, D. N., Wells, J. G., Greene, K. D., Popovic, T., Giono-Cerezo, S., Wachsmuth, I. K. \& Tauxe, R. V. (1995). The emerging diversity of the electrophoretic types of Vibrio cholerae in the Western Hemisphere. J Infect Dis 172, 173-179.

Faruque, S. M., Ahmed, K. M., Abdul Alim, A. R. M., Qadri, F., Siddique, A. K. \& Albert, M. J. (1997a). Emergence of a new clone of toxigenic Vibrio cholerae O1 biotype ElTor displacing $V$. cholerae $\mathrm{O} 139$ Bengal in Bangladesh. J Clin Microbiol 35, 624-630.

Faruque, S. M., Ahmed, K. M., Siddique, A. K., Zaman, K., Abdul Alim, A. R. M. \& Albert, M. J. (1997b). Molecular analysis of toxigenic Vibrio cholerae O139 Bengal strains isolated in Bangladesh between 1993 and 1996: evidence for emergence of a new clone of the Bengal vibrios. J Clin Microbiol 35, 2299-2306.

Faruque, S. M., Albert, M. J. \& Mekalanos, J. J. (1998). Epidemiology, genetics and ecology of toxigenic Vibrio cholerae. Microbiol Mol Biol Rev 62, 1301-1314.

Felsenstein, J. (1993). PHYLIP package, version 3·5. Seattle, WA: University of Washington (http://evolution.genetics.washington.edu/phylip.html).

Fusté, M. C., Pineda, M. A., Palomar, J., Viñas, M. \& Lorén, J. G. (1996). Clonality of multidrug-resistant nontypeable strains of Haemophilus influenzae. J Clin Microbiol 34, 2760-2765.

Gibson, D. T. (1971). Assay of enzymes of aromatic metabolism. Methods Microbiol 6A, 463-478.

Harvell, C. D., Kim, K., Burkholder, J. M. \& 10 other authors (1999). Emerging marine diseases - climate links and anthropogenic factors (review). Science 285, 1505-1510.

Jiang, S. C., Matte, M., Matte, G., Huq, A. \& Colwell, R. R. (2000). Genetic diversity of clinical and environmental isolates of Vibrio cholerae determined by amplified fragment length polymorphism fingerprinting. Appl Environ Microbiol 66, 148-153.

Kaper, J. B., Bradford, H. B., Roberts, N. C. \& Falkow, S. (1982). Molecular epidemiology of Vibrio cholerae in the U.S. Gulf Coast. J Clin Microbiol 16, 129-134.

Kaper, J. B., Morris, J. G. \& Levine, M. M. (1995). Cholera. Clin Microbiol Rev 8, 48-86.

Karaolis, D. K., Lan, R. \& Reeves, P. R. (1994). Molecular evolution of the seventh-pandemic clone of Vibrio cholerae and its relationship to other pandemic and epidemic V. cholerae isolates. J Bacteriol 176, 6199-6206.

Karaolis, D. K., Lan, R. \& Reeves, P. R. (1995). The sixth and seventh cholera pandemics are due to independent clones separately derived from environmental, nontoxigenic, non-O1 Vibrio cholerae. J Bacteriol 177, 3191-3198.

Karaolis, D. K., Johnson, J. A., Bailey, C. C., Boedeker, E. C., Kaper, J. B. \& Reeves, P. R. (1998). A Vibrio cholerae pathogenicity island associated with epidemic and pandemic strains. Proc Natl Acad Sci U S A 95, 3134-3139.

Kataeva, I. A. \& Golovleva, L. A. (1990). Catechol 2,3-dioxygenases from Pseudomonas aeruginosa 2x. Methods Enzymol 188, 115-121.

Maynard Smith, J., Smith, N. H., O'Rourke, M. \& Spratt, B. G. (1993). How clonal are bacteria? Proc Natl Acad Sci U S A 90, 4384-4388.

Mukhopadhyay, A. K., Basu, A., Garg, P., Bag, P. K., Ghosh, A., Bhattacharya, S. K., Takeda, Y. \& Nair, G. B. (1998). Molecular epidemiology of reemergent Vibrio cholerae O139 Bengal in India. J Clin Microbiol 36, 2149-2152.

Nei, M. (1972). Genetic distance between populations. Am Nat 106, 283-292.

Nei, M. (1978). Estimation of average heterozygosity and genetic distance from a small sample of individuals. Genetics 89, 583-590.

Popovic, T., Fields, P. I., Olsvik, O. \& 11 other authors (1995). Molecular subtyping of toxigenic Vibrio cholerae O139 causing epidemic cholera in India and Bangladesh, 1992-1993. J Infect Dis 171, 122-127.

Ramamurthy, T., Garg, S., Sharma, R. \& 8 other authors (1993). Emergence of a novel strain of Vibrio cholerae with epidemic potential in Southern and Eastern India. Lancet 341, 703-704.

Ravel, J., Knight, I. T., Monahan, C. E., Hill, R. T. \& Colwell, R. R. (1995). Temperature-induced recovery of Vibrio cholerae from the viable but nonculturable state: growth or resuscitation? Microbiology 141, 377-383.

Rivera, I. G., Chowdhury, M. A. R., Huq, A., Jacobs, D., Martins, M. T. \& Colwell, R. R. (1995). Enterobacterial repetitive intergenic consensus sequences and the PCR to generate fingerprints of genomic DNAs from Vibrio cholerae O1, O139 and non-O1 strains. Appl Environ Microbiol 61, 2898-2904.

Rohlf, F. J. (1993). Numerical taxonomy and multivariate analysis system, version 1·80. New York: Exeter Software.

Salles, C. A. \& Momen, H. (1991). Identification of Vibrio cholerae by enzyme electrophoresis. Trans $R$ Soc Trop Med Hyg 85, 544-547.

Sanchez, J. L. \& Taylor, D. N. (1997). Cholera. Lancet 349, 1825-1830.

Selander, R. K., Caugant, D. A., Ochman, H., Musser, J. M., Gilmour, M. N. \& Whittam, T. S. (1986). Methods of multilocus enzyme electrophoresis for bacterial population genetics and systematics. Appl Environ Microbiol 51, 873-884.

Sneath, P. H. A. \& Sokal, R. R. (1973). Numerical Taxonomy. San Francisco: Freeman.

Stroeher, U. H., Parasivam, G., Dredge, B. K. \& Manning, P. A. (1997). Novel Vibrio cholerae O139 genes involved in lipopolysaccharide biosynthesis. J Bacteriol 179, 2740-2747.

Wachsmuth, I. K., Evins, G. M., Fields, P. I., Olsvik, O., Popovic, T., Bopp, C. A., Wells, J. G., Carrillo, C. \& Blake, P. A. (1993). The molecular epidemiology of cholera in Latin America. J Infect Dis 167, 621-626.

Waldor, M. K. \& Mekalanos, J. J. (1996). Lysogenic conversion by a filamentous phage encoding cholera toxin. Science 272, 19101914.

Whittam, T. S. (1995). Genetic population structure and pathogenicity in enteric bacteria. In Population Genetics of Bacteria, pp. 217-245. Edited by S. Baumberg, J. P. Young, E. M. H. Wellington \& J. R. Saunders. Cambridge: Cambridge University Press.

Young, J. P. W. (1989). The population genetics of bacteria. In Genetics of Bacterial Diversity. Edited by D. A. Hopwood \& K. F. Chater. London: Academic Press.

Received 20 December 1999; revised 22 May 2000; accepted 26 June 2000. 